\title{
Antioxidant capacity of anthocyanins from acerola genotypes
}

\author{
Capacidade antioxidante de antocianinas de genótipos de acerola \\ Vera Lúcia Arroxelas Galvão de LIMA ${ }^{1 *}$, Enayde Almeida MELO' ${ }^{1}$ \\ Irapuan Oliveira PINHEIRO², Nonete Barbosa GUERRA ${ }^{3}$
}

\begin{abstract}
Anthocyanins from 12 acerola genotypes cultivated at the Active Germplasm Bank at Federal Rural University of Pernambuco were isolated for antioxidant potential evaluation. The antioxidant activity and radical scavenging capacity of the anthocyanin isolates were measured according to the $\beta$-carotene bleaching method and 1,1-diphenyl-2-picrylhydrazyl (DPPH) free radical scavenging assay, respectively. The antioxidant activity varied from 25.58 to $47.04 \%$ at $0.2 \mathrm{mg} \cdot \mathrm{mL}^{-1}$, and it was measured using the $\beta$-carotene bleaching method. The free radical scavenging capacity increased according to the increase in concentration and reaction time by the DPPH assay. At $16.7 \mu \mathrm{g} . \mathrm{mL}^{-1}$ concentration and after 5 minutes and 2 hours reaction time, the percentage of scavenged radicals varied from 36.97 to $63.92 \%$ and 73.27 to $94.54 \%$, respectively. Therefore, the antioxidant capacity of acerola anthocyanins varied amongst acerola genotypes and methods used. The anthocyanins present in this fruit may supply substantial dietary source of antioxidant which may promote health and produce disease prevention effects. Keywords: anthocyanins; acerola (Malpighia emarginata D.C.); genotypes; $\beta$-carotene/linoleic acid model system; DPPH free radical scavenging.
\end{abstract}

\section{Resumo}

Antocianinas de acerolas, isoladas de 12 genótipos cultivados no Banco Ativo de Germoplasma da Universidade Federal Rural de Pernambuco, foram testadas quanto à atividade antioxidante e à capacidade de sequestrar radicais livres através do sistema modelo $\beta$-caroteno/ácido linoleico e do radical livre 1,1-difenil-2-picrilhidrazila (DPPH), respectivamente. A atividade antioxidante das antocianinas, na concentração de $0,2 \mathrm{mg} \cdot \mathrm{mL}^{-1}$, variou de 28,58 a 47,07\%. A capacidade de sequestrar radical livre DPPH aumentou com a concentração e tempo de reação. Na concentração $16,7 \mu \mathrm{g} \cdot \mathrm{mL}^{-1}$ e após 5 minutos e 2 horas de reação, o percentual variou de 36,97 a $63,92 \%$ e de 73,27 a $94,54 \%$, respectivamente. Portanto, a capacidade antioxidante das antocianinas extraídas de acerola variou entre os genótipos e o método utilizado. As antocianinas presentes nesse fruto são uma fonte dietética de antioxidante e assim podem atuar na promoção da saúde e na prevenção de doenças.

Palavras-chave: antocianinas; acerola (Malpighia emarginata D.C.); genótipos; sistema modelo ß-caroteno/ácido linoleico; capacidade de sequestro do DPPH.

\section{Introduction}

In the past few years epidemiological studies have suggested that the intake of fruits and vegetables is beneficial to health and contribute to the prevention of degenerative diseases (AMES; SHIGENAGA; HAGEN, 1993). The protection provided against diseases by fruits and vegetables has been attributed to the various phytochemical antioxidants contained in these foods, in addition to the well-known vitamins $\mathrm{C}$ and $\mathrm{E}$ and carotenoids (WANG; CAO; PRIOR, 1996; VINSON et al., 1998). The antioxidant capacity can be largely attributed to phenolic substances, in particular to anthocyanins. These compounds are water-soluble and belong to the flavonoids class, widely distributed among flowers, fruits, and vegetables, which are responsible for the bright colours such as orange, red, and blue (FRANCIS, 1989).

The anthocyanins are glycosides of polyhydroxy and polymethoxy derivatives of 2-phenylbenzopyrylium (flavylium cation). The differences between individual anthocyanins relate to the number of hydroxyl groups, the nature and number of sugar attached to the molecule, the position of this attachment, and the nature and number of aliphatic or aromatic acids attached to sugars in the molecule (FRANCIS, 1989). According to Macheix, Fleurit and Billot (1990), there are differences in the nature and levels of the anthocyanins in several cultivars of the same fruit. Apart from imparting colour to fruits, anthocyanins show ability to act as free radical scavengers and metal chelators (KÄHKÖNEN; HEINONEN, 2003). In a recent review, Castaňeda-Ovando et al. (2009) reported major advances in the chemical investigation of anthocyanins, emphasising the effects of $\mathrm{pH}$, co-pigmentation, metal ion complexation, and antioxidant activity on their stability.

Acerola (Malpighia emarginata D.C.), known to be rich in vitamin $\mathrm{C}$, has been considered one of the most important natural sources of this vitamin. Although the vitamin $\mathrm{C}$ content decreases during ripening, mature fruits still show high levels of this vitamin. Vendramini and Trugo (2000) and Assis, Lima 
and Oliveira (2001) reported vitamin C concentration of 1,074 , and $957 \mathrm{mg} .100 \mathrm{~g}^{-1}$ of ripe fruits pulp, respectively.

Much of the world production of acerola occurs in Brazil, where it has been widely spread due to its good adaptation to the soil and climate (JOHNSON, 2003). Due to the need for identifying promising genetic material, the Federal Rural University of Pernambuco - UFRPE established, in June 1998, an acerola Active Germoplasm Bank (AGB). The red color of this ripe fruit is due the anthocyanins content and Lima et al. (2006) reported the presence of two aglycons which were identified as cyanidin and pelargonidin. The total anthocyanin content from these genotypes varied from 64.6 to $6.4 \mathrm{mg} .100 \mathrm{~g}^{-1}$ of ripe fruits pulp (LIMA; MELO; GUERRA, 2007).

Previous studies have focused mainly on the acerola chemical composition (VENDRAMINI; TRUGO, 2000; LIMA et al., 2005; RIGHETTO; NETTO; CARRARO, 2005; MEZADRI et al., 2008). However, as far as we know, no studies on antioxidant activity of anthocyanins isolated from this fruit have been published. Therefore, the aim of this research was to assay the potential antioxidant of anthocyanins from 12 acerola genotypes.

\section{Materials and methods}

\subsection{Chemicals}

Butylated hydroxytoluene (BHT), $\beta$-carotene, and 1, 1-diphenyl-2-picrylhydrazyl (DPPH) were purchased from Sigma Chemical Co. (St. Louis, MO), while the linoleic acid was purchased from Fluka (Milwaukee, WI). All other reagents were of analytical grade.

\subsection{Fruits}

Twelve genotypes of acerola grown in a non-commercial orchard, called Active Germplasm Bank of Federal Rural University of Pernambuco (Brazil) were used in this study. These genotypes were also used in a previous study (MUSSER et al., 2004; LIMA et al., 2003) and were selected because they were the first to be grown in this Germoplasm Bank. The genotypes were codified with the numbers: $02,03,04,05,06,07,08,11,12,13$, 14 , and 15 . About 1 to $2 \mathrm{~kg}$ of full-ripe fruits were collected from each genotype in the morning, refrigerated, and transported to the Food Analysis and Experimentation Laboratory of the Nutrition Department of UFPE, where this study was carried out. Ripeness was determined on the basis of each genotype characteristic red colour. Fruits from each genotype were sorted to discard overripe or damaged berries and then crushed in a domestic juice extractor (Walita, Brazil) with no addition of water and stored at $-18^{\circ} \mathrm{C}$ until analysis. All further procedures were performed under reduced-light conditions.

\subsection{Anthocyanins extraction}

The anthocyanins were extracted from thawed acerola pulps (200 to $500 \mathrm{~g}$ ) according to Rodriguez-Saona and Wrolstad (2001), with minor modifications. In brief, the samples were blended with acetone and filtered on a Büchner funnel using
Whatman no. 1 paper. The filter cake residues were reextracted with acetone until a clear solution was obtained. Filtrates were combined, shaken in a separator funnel with 2 volumes of chloroform, and stored overnight at $4{ }^{\circ} \mathrm{C}$. The addition of chloroform resulted in phase separation between the aqueous portion (which contains anthocyanins, phenolics, sugars, organic acids, and other water-soluble compounds) and the bulk phase (which contains lipids, carotenoids, chlorophyll pigments, and other nonpolar compounds). The nonpolar phase was discarded, and the upper aqueous layer was colleted and residual acetone removed using a rotary evaporator at $40{ }^{\circ} \mathrm{C}$ (5-10 minutes), and then stored at $-18{ }^{\circ} \mathrm{C}$ until analysis.

\subsection{Anthocyanins purification}

The anthocyanins were purified following the procedures described by Rodriguez-Saona and Wrolstad (2001) with slight modifications. In brief, the aqueous extract ( 5 to $10 \mathrm{~mL}$ ) was passed through $\mathrm{C}_{18}$ Sep-Pak cartridges (Plus, $360 \mathrm{mg}$, Waters Associates, Milford, MA) previously activated with methanol followed by $0.01 \%$ aqueous $\mathrm{HCl}$. The anthocyanins and other polyphenolics were adsorbed onto the Sep-Pak column while sugars and acids and other water-soluble compounds were removed by washing the column with $0.01 \%$ aqueous $\mathrm{HCl}$. In order to remove the ascorbic acid, the cartridges were rinsed with $0.01 \%$ aqueous $\mathrm{HCl}$ using a volume 10 times the anthocyanins aqueous extract passed through the cartridges. The phenolic compounds other than anthocyanins were removed from the column by washing with ethyl acetate and anthocyanins were subsequently eluated with methanol containing $0.01 \% \mathrm{HCl}(\mathrm{v} / \mathrm{v})$. The methanolic extract was then stored at $-18{ }^{\circ} \mathrm{C}$ for further procedures. The $0.01 \%$ aqueous $\mathrm{HCl}$ from the last washing was collected and used to verify the ascorbic acid presence by titration with the 2,6-Dichloroindophenol reagent as described by AOAC method 967.21 (ASSOCIATION..., 1990).

\subsection{Precipitation of anthocyanins}

The anthocyanins were precipitated according to Espín et al. (2000). The methanolic extracts were concentrated under vacuum to dryness. The diethyl ether was added to the residue in order to obtain the precipitated pigments. The diethyl ether layer was removed and the precipitated powders containing anthocyanins were collected, centrifuged for 20 minutes at $2500 \times \mathrm{g}$, and dried under nitrogen gas. The dried anthocyanins were kept in small dark vials, flushed with nitrogen gas, and stored at $4{ }^{\circ} \mathrm{C}$ for further analysis.

\section{6 $\beta$-carotene bleaching assay}

The evaluation of the antioxidant activity of anthocyanins from each acerola genotype was based on coupled oxidation of $\beta$-carotene and linoleic acid and determined following the procedure described by Marco (1968) and modified by Hammerschmidt and Pratt (1978). This method consists of measuring the bleaching of $\beta$-carotene resulting from oxidation by degradation products of linoleic acid. 
$\beta$-carotene $(0.1 \mathrm{mg})$ was added to a round-bottom flask together with linoleic acid $(20 \mathrm{mg})$ and Tween $40(200 \mathrm{mg})$, all dissolved in chloroform. After evaporation to dryness, under vacuum at $50{ }^{\circ} \mathrm{C}$ by a rotary evaporator, $50 \mathrm{~mL}$ of distilled water, saturated for 30 minutes with oxygen gas, were slowly added to the flask and the mixture was vigorously shaken. The anthocyanins' powder from each acerola genotype was solubilized in methanol containing $0.01 \% \mathrm{HCl}$, and $0.2 \mathrm{~mL}$ were added to $5 \mathrm{~mL}$ of the $\beta$-carotene/linoleic acid emulsion in order to obtain the final concentration of $0.2 \mathrm{mg} \cdot \mathrm{mL}^{-1}$. An ethanolic solution of butylated hydroxytoluene (BHT) was used for comparative purposes, and it was prepared to obtain the same final concentration of anthocyanin solutions $\left(0.2 \mathrm{mg} \cdot \mathrm{mL}^{-1}\right)$. The control sample contained $0.2 \mathrm{~mL}$ water and $5 \mathrm{~mL} \beta$-carotene/linoleic acid emulsion. The blank used to zero the spectrophotometer contained all the above mentioned chemicals except $\beta$-carotene. As soon as the emulsion was added to each tube, the zero time absorbance was read at $470 \mathrm{~nm}$ on a Genesys ${ }^{\mathrm{TM}} 10$ vis spectrophotometer using $1 \mathrm{~cm}$ path length cells. Subsequent absorbance readings were recorded at 15 minutes intervals by keeping the samples in a water bath at $50{ }^{\circ} \mathrm{C}$ during 120 minutes. All determinations were performed in triplicate. The antioxidant activity (AA) of the anthocyanins in each acerola genotype was calculated as the percent inhibition in relation to the control using the following Equation (1) (AL-SAIKHAN; HOWARD; MILLER JUNIOR., 1995):

$A A=\frac{\text { Degradation rate of control }- \text { Degradation rate of sample }}{\text { Degradation rate of control }} \times 100$

\subsection{DPPH (1, 1-diphenyl-2-picrylhydrazyl) free radical-scavenging capacity}

The free radical-scavenging activity of the anthocyanins genotypes was measured using the method described by BrandWilliams, Cuvelier and Berset (1995) with some modifications. Briefly, it is described as follows: the anthocyanin powder from each acerola genotype was solubilized in methanol and $0.1 \mathrm{~mL}$ with different concentrations (1.0, 0.5 and $\left.0.1 \mathrm{mg} \cdot \mathrm{mL}^{-1}\right)$ and pipetted into screw-cap test tubes containing $5.9 \mathrm{~mL}$ of $0.1 \mathrm{mM}$ methanolic DPPH solution. The final concentrations were 16.7, 8.3, and $1.7 \mu \mathrm{g} . \mathrm{mL}^{-1}$, respectively. A methanolic solution of BHT was used for comparative purposes, and it was prepared to obtain the same final concentrations of the anthocyanin solutions. The reaction mixtures were shaken, kept in the dark at ambient temperature $\left(23 \pm 1^{\circ} \mathrm{C}\right)$, and the decrease in absorbance at $517 \mathrm{~nm}$ was measured at $5,15,30,60,90$, and 120 minutes using a Genesys ${ }^{\mathrm{TM}} 10$ vis spectrophotometer. Methanol was used to zero the spectrophotometer and the blank sample contained $0.1 \mathrm{~mL}$ of methanol and $5.9 \mathrm{~mL}$ of DPPH. All experiments were carried out in triplicate.

For each anthocyanins concentration, the results were calculated using the following formula and expressed as percentage of radicals scavenged using Equation (2) (MILIAUSKAS; VENSKUTONIS; VAN BEEK, 2004):

$\%$ radical scavenging capacity $=\left[\frac{\left(A_{B}-A_{A}\right)}{A_{B}}\right] \times 100$ where: $A_{B}=$ absorption of blank sample $\left(t=0\right.$ minute); $A_{A}=$ absorption of tested anthocyanin solutions $(t=$ for each different time)

\subsection{Statistical analysis}

The data were analysed using Statistic software package version 5.5 (StatSoft, Inc., Tulsa, USA). The differences between the means were analyzed by ANOVA test and Tukey test in order to compare the antioxidant activity of the anthocyanins from different genotypes of acerola. The mean values and standard deviations of the means were reported. Differences at $\mathrm{p}<0.05$ were considered to be significant.

\section{Results and discussion}

\subsection{Removal of ascorbic acid}

Fruits contain large amounts of sugar, organic acids, flavonoids, and other compounds that can show antioxidant and/or prooxidant action. Therefore, the isolation of bioactive components in extracts would certainly help to ascertain the individual potency of this compound. Solid-Phase Extraction (SPE) is a separation technique that was used to purify the sample and to obtain the desired extract. Successful SPE requires careful consideration of nature of the SPE sorbent, the solvent systems to be used, and their influence on the analyte of interest (DEAN, 1998). This technique is effective and versatile and can be used for a number of purposes, such as purification, tracing enrichment, desalting, derivatisation, and class fractionation.

No ascorbic acid was detected in any of the samples by following the method detailed in the materials and methods section. Thus, the separation technique used in this study was effective for removing ascorbic acid, an antioxidant compound which could interfere in the antioxidant evaluation of the anthocyanins isolated from acerola genotypes. This result corroborates the findings of Heinonen, Lehtonen and Hopia (1998) and Espín et al. (2000), who also reported that the ascorbic acid was removed after SPE treatment by using the $\mathrm{C}_{18}$ Sep-Pak cartridges.

\section{$3.2 \beta$-carotene bleaching assay}

The antioxidant activities of 12 anthocyanins acerola genotypes and a standard antioxidant (BHT) are presented in the Figure 1. It can be observed that amongst the genotypes, the anthocyanins isolated from genotype 02 showed the highest percentage of antioxidant activity (47.07\%). The percentage of BHT antioxidant activity was higher than that of acerola anthocyanins. This is in agreement with the results obtained by other authors who demonstrated that BHT acted as the best inhibitor of $\beta$-carotene bleaching method (GUERRA; MELO; MANCINI FILHO, 2005; TEPE et al., 2005).

The oxidation inhibition percentage of genotype 02 was statistically similar to the others, except for genotype 05 and 11 ( $\mathrm{p}<0.05)$, which had the lowest $(31.73$ and $28.58 \%$, respectively). Connor et al. (2002) also found significant differences in the antioxidant activity of nine genotypes of 
blueberry fruit. Velioglu et al. (1998) reported that $80 \%$ aqueous methanolic extracts from blueberry and sweet cherry showed strong antioxidant activity ( 92.1 and $82.5 \%$, respectively) using the $\beta$-carotene bleaching method. On the other hand, using this same method, Cordenunsi et al. (2005) found that $70 \%$ aqueous methanolic containing 5\% acetic acid extracts from Dover, Campineiro, and Oso Grande strawberry cultivars presented antioxidant activities of 55.2, 51.7, and 56.6\%, respectively. Different extraction procedures can strongly influence the composition of the extracts and their antioxidant activity. Therefore, the produced raw extracts contain also other substances than anthocyanins, such as sugars, organic acids, and other phenolic compounds which can interfere in the antioxidant evaluation. In order to avoid interference of anthocyanin profiles isolated from the acerola genotypes in the antioxidant test, the same anthocyanins concentration was used. Therefore, the variation in antioxidant activity found among the genotypes can be explained on the basis of their anthocyanin chemical characteristics, which are inherent to each genotype.

\subsection{DPPH radical-scavenging capacity}

The reduction of DPPH by antioxidant compounds results in a loss of absorbance. Thus, the degree of discoloration of the solution indicates the scavenging efficiency of the added substance. When DPPH reacts with an antioxidant compound, which can donate hydrogen atoms, it is reduced and its colour changes from deep-violet to light-yellow. Anthocyanins absorb at this wavelength as well, but their contribution to total absorbance was small owing to their low concentration in the test (KÄHKÖNEN et al., 2003). Many authors have used different reaction times such as 5 minutes (NAKAJIMA et al., 2004), 15 minutes (MILIAUSKAS; VENSKUTONIS; VAN BEEK, 2004), 25 minutes (DUARTE-ALMEIDA et al., 2006), or $15,30,45$, and 60 minutes in the same assay (MELO et al., 2008).

Figures 2-4 show the antioxidant capacity of the anthocyanins isolated from acerola genotypes at different concentrations. It can be observed that the potential free radical scavenging varied according to the genotypes and increased with the increase of concentration and reaction time. Oki et al. (2002) reported that in anthocyanic fractions obtained from sweet potato cultivars, DPPH radical scavenging activity increased with the increase of the anthocyanin content.

After 5 minutes of reaction time and at the highest concentration tested (Figure 2), the anthocyanins isolated from genotype 14 exhibited significantly the highest DPPH radical scavenging capacity (63.92\%), which was higher than those reported by Kähkönen et al. (2003). These authors demonstrated that after 4 minutes of reaction time and using the same concentration tested $\left(16.7 \mu \mathrm{g} . \mathrm{mL}^{-1}\right)$, the anthocyanins isolated from blackberry presented the most efficient DPPH radical scavenging capacity (58\%), followed by bilberry (52\%) and cowberry (36\%). The anthocyanin extracts of blueberry, rabbiteye blueberry, black currant, chokeberry, and elderberry showed relatively similar activities, varying approximately from 45 to $55 \%$ after 5 minutes reaction time and at $1 \mathrm{mg} \cdot \mathrm{mL}^{-1}$ by DPPH test (NAKAJIMA et al., 2004). Although the anthocyanins from genotypes 14 and 03 presented the highest radical scavenging capacities, they did not differ significantly from genotypes 04,08 , and 12 after 2 hours of reaction time (Figure 2).

In this study, BHT showed significantly the lowest value after 5 minutes of reaction time at all concentrations tested (Figures 2-4). The percentages of radical scavenging were 17.36, 9.98, and $3.12 \%$ at $16.7,8.3$, and $1.7 \mu \mathrm{g} \cdot \mathrm{mL}^{-1}$ final concentrations, respectively. Bondet, Brand-Willians and Berset (1997) reported

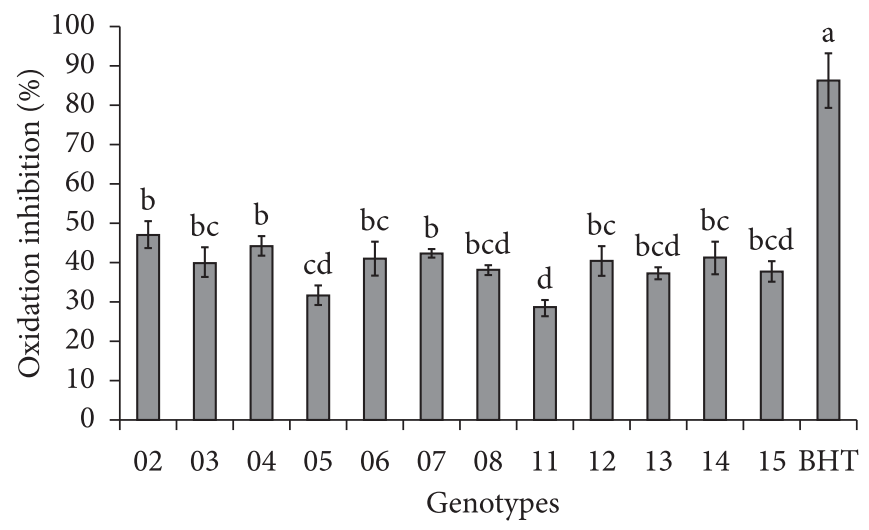

Figure 1. Antioxidant activity of anthocyanins isolated from 12 acerola genotypes and standard antioxidant (BHT) at $0.2 \mathrm{mg} \cdot \mathrm{mL}^{-1}$ concentration assayed by $\beta$-carotene bleaching method. Reported values are means \pm standard deviations of three replications. Bars sharing the same letter are not significantly different from one another ( $\mathrm{p}>0.05$ Tukey test).

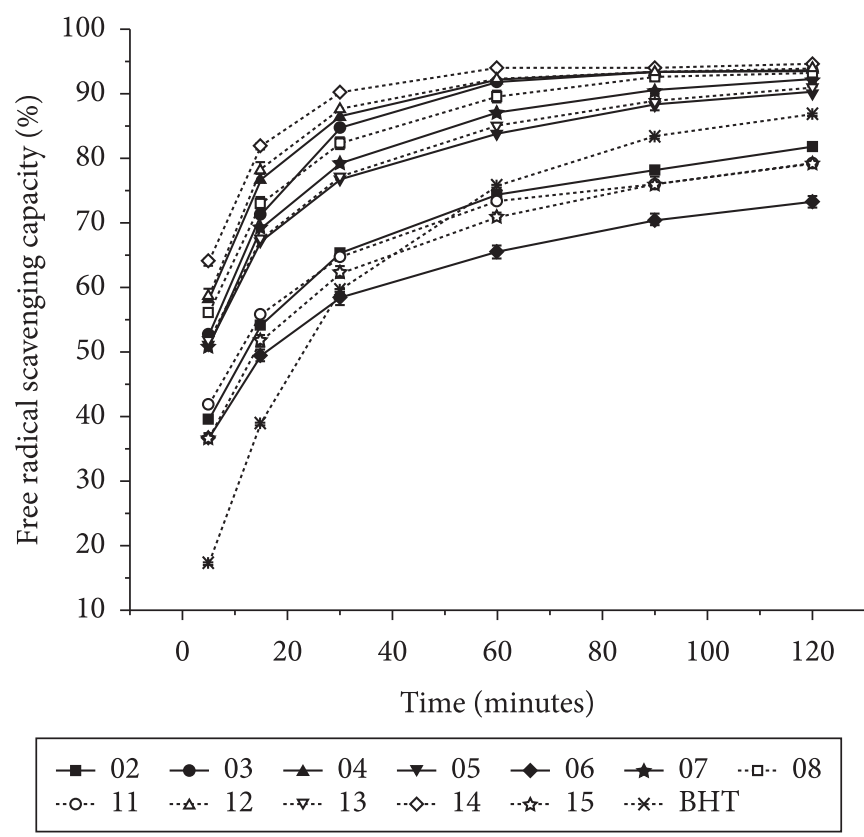

Figure 2. Free radical scavenging capacity (\%) of anthocyanins isolated from 12 acerola genotypes and BHT at $16.7 \mu \mathrm{g} \cdot \mathrm{mL}^{-1}$ final concentration assayed by the DPPH method. Data are presented as the means \pm SD of triplicate determinations. 
that BHT reacts very slowly with DPPH reaching a steady state within 5 hours. Other authors also reported that BHT had low activity by the DPPH method (TEPE et al., 2005; RUFINO et al., 2009; SHARMA; BHAT, 2009)). Thus, the more rapidly the absorbance decreases and consequently the percentage radical scavenging increases, the more potent the antioxidant activity of the compound in terms of hydrogen donating ability.

As can be observed in Figure 3, the anthocyanins from genotype 14 were the most efficient DPPH radical scavenger after 5 minutes of reaction time (42.35\%). However, they did not differ significantly from genotypes $04(40.22 \%)$ and 08 (39.43\%). Kähkönen et al. (2003) using the same concentration $\left(8.3 \mu \mathrm{g} \cdot \mathrm{mL}^{-1}\right)$ and after 4 minutes of reaction time, reported that anthocyanin isolates from blackberry, bilberry, and cowberry showed that DPPH radical scavenging capacities were 38, 38 , and $25 \%$, respectively. After 2 hours of reaction time, the anthocyanins from genotypes 03 and 14 showed, significantly, the highest values (75.64 and $75.32 \%$ ) but they were statistically similar to the value presented by the anthocyanins isolated from genotype $04(72.64 \%)$.

Despite the low concentration used $\left(1.7 \mu \mathrm{g} \cdot \mathrm{mL}^{-1}\right)$, the anthocyanins from acerola were still capable of free radical scavenging (Figure 4). After 5 minutes of reaction time, the anthocyanins from genotype 14 showed the highest percentage of inhibition (11.03\%), but they did not differ statistically from those of genotypes $03,04,05,08$, and 12 . These results are in agreement with those reported by Kähkönen et al. (2003) who found 12,13 , and $9 \%$ DPPH radical scavenging activity in the anthocyanin isolates from blackberry, bilberry, and cowberry, respectively using the same concentration tested $\left(1.7 \mu \mathrm{g} \cdot \mathrm{mL}^{-1}\right)$ and 4 minutes of reaction time. However, in this concentration and after 2 hours of reaction time, the BHT was the most efficient free radical scavenger $(23 \%)(\mathrm{p}<0.05)$.

\subsection{Comparison of the methods}

Several antioxidant activity methods have been used to monitor and compare the antioxidant activity of foods. According to Sánchez-Moreno (2002), the antioxidant tests in food and biological systems could be classified into two groups: assays used to evaluate lipid peroxidation, in which the degree of oxidation inhibition is measured, and those used to measure free radical scavenging (e.g. $\beta$-carotene bleaching method and stable radical DPPH assay).

The data obtained for anthocyanins by DPPH and $\beta$-carotene bleaching methods indicate that the latter is not very appropriate for the evaluation of anthocyanins antioxidant activity. The $\beta$-carotene bleaching method conditions could explain the results found in this study because it is an accelerated test which employs high temperature and oxygen supply bringing the risk of undesirable alterations of the studied compounds. On the other hand, the DPPH method uses very mild experimental conditions, which are an advantage, especially in this study because anthocyanins are sensible to oxygen and high temperature (MARKAKIS, 1982).

Since specificity and sensibility are different for each method used, it was impossible to use equal amounts of antioxidant for each test. Thus, the effect of using different amounts of antioxidants in the different tests makes it difficult to compare the obtained results. On the other hand, methods of measuring antioxidant activity are extremely dependent on the conditions

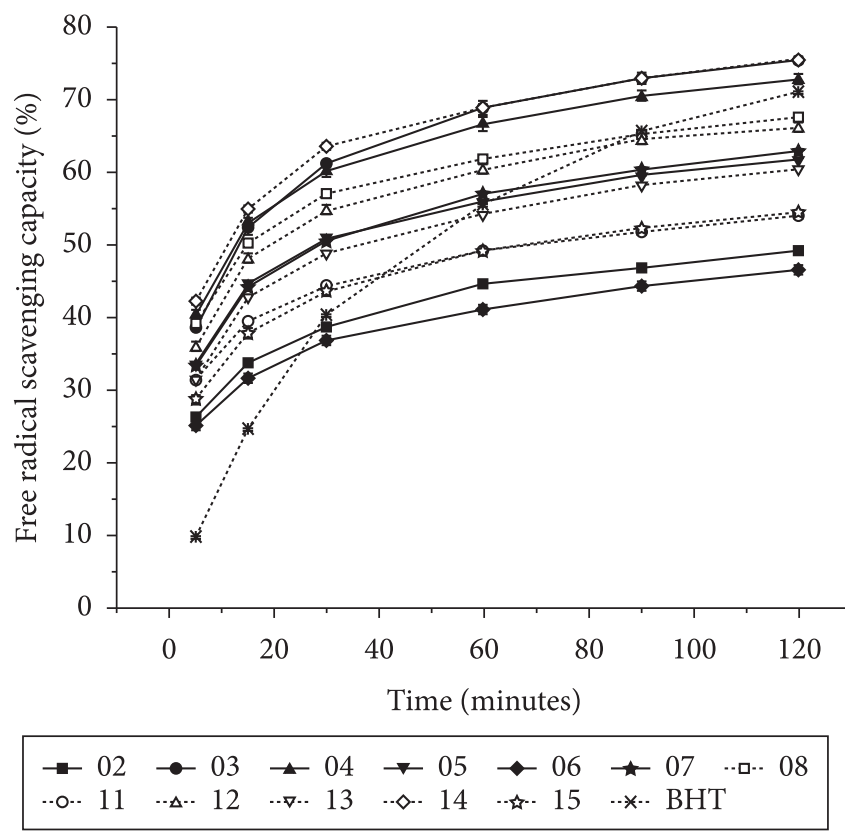

Figure 3. Free radical scavenging capacity (\%) of anthocyanins isolated from 12 acerola genotypes and BHT at $8.3 \mu \mathrm{g} \cdot \mathrm{mL}^{-1}$ final concentration assayed by the DPPH method. Data are presented as the means \pm SD of triplicate determinations.

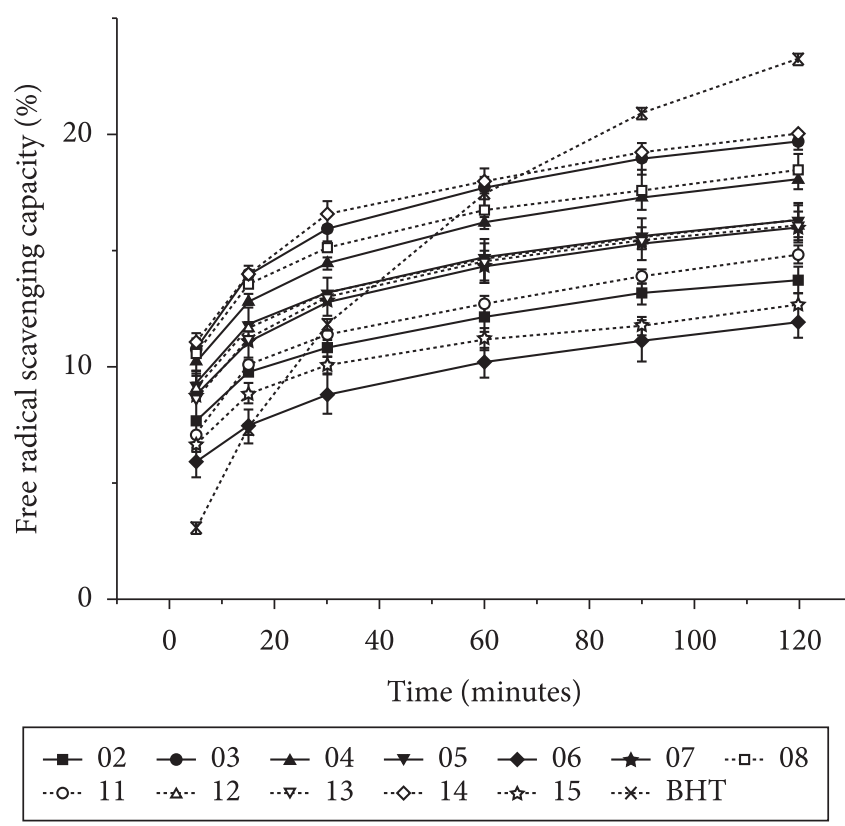

Figure 4. Free radical scavenging capacity (\%) of anthocyanins isolated from 12 acerola genotypes and BHT at $1.7 \mu \mathrm{g} \cdot \mathrm{mL}^{-1}$ final concentration assayed by DPPH method. Date is presented as the means \pm SD of triplicate determinations. 
used and the substrates or products monitored. Taking into account these considerations, the methods used did not show the same results for the antioxidant activity. Tabart et al. (2009) compared the antioxidant capacities of standard compounds measured using various tests and concluded that most compounds showed significant differences in free radical scavenging activity according to the method used. The necessity of evaluating the effectiveness of an antioxidant using different methods was stressed in this study: if the anthocyanins had only been tested using the $\beta$-carotene bleaching method, they would have been considered to be a weak to medium antioxidant. However, the strong antioxidant potential of anthocyanins was proven many times by the DPPH method.

\section{Conclusions}

Solid-Phase Extraction (SPE) using $\mathrm{C}_{18}$ Sep-Pak cartridges and the procedure described in this study to remove ascorbic acid from aqueous anthocyanin acerola extracts proved an effective way to guarantee the absence of this acid. Independently of the methods used in this study, all anthocyanins isolated from acerola genotypes possess antioxidant properties. In the $\beta$-carotene bleaching method, the anthocyanins isolated among most acerola genotypes exhibited similar antioxidant activity. Nevertheless, although the concentration of these pigments and reaction time influenced the DPPH test, the anthocyanins isolated from acerola exhibited strong ability as free radical scavenger. In addition to the fact that acerola is an excellent source of vitamin $\mathrm{C}$, the anthocyanins present in this fruit may supply substantial dietary source of antioxidant, which may promote health and produce disease prevention effects.

\section{References}

AL-SAIKHAN, M. S.; HOWARD, L. R.; MILLER JUNIOR, J. C. Antioxidant activity and total phenolics in different genotypes of potato (Solanum tuberosum, L). Journal of Food Science, v. 60, p. 341-343, 1995.

AMES, B. N.; SHIGENAGA, M. K.; HAGEN, T. M. Oxidants, antioxidants, and the degenerative diseases of aging. Proceedings of National Academy of Sciences of the United States of America, v. 90, p. 7915-7922, 1993.

ASSIS, S. A.; LIMA, D. C.; OLIVEIRA, O. M. M. F. Activity of pectinmethylesterase, pectin content and vitamin $C$ in acerola fruit at various stages of fruit development. Food Chemistry, v. 74, p. 133-137, 2001.

Association of Official Analytical Chemists - AOAC. Official methods of analysis of the Association of Official Analytical Chemists, 15th ed. Arlington: Association of Official Analytical Chemists, 1990. p. 1058-1059.

BONDET, V.; BRAND-WILLIAMS, W.; BERSET C. Kinetics and mechanisms of antioxidant activity using the DPPH free radical method. Lebensmittel-Wissenschaft und Technologie, v. 30, p. 609-615, 1997.

BRAND-WILLIAMS, W.; CUVELIER, M. E.; BERSET, C. Use of a free method to evaluate antioxidant activity. Lebensmittel-Wissenschaft und Technologie, v. 28, p. 25-30, 1995.

CASTAÑEDA-OVANDO, A. et al. Chemical studies of anthocyanins: a review. Food Chemistry, v. 113, n. 4, p. 859-871, 2009.
CONNOR, A. M. et al. Genotypic and environmental variation in antioxidant activity among blueberry cultivars. Acta Horticulturae, v. 574, p. 209-213, 2002.

CORDENUNSI, B. R. et al. Effects of temperature on the chemical composition and antioxidant activity of three strawberry cultivars. Food Chemistry, v. 91, p. 113-121, 2005.

DEAN, J. R. Extraction methods for environmental analysis. Chichester: John Wiley \& Sons, 1998.

DUARTE-ALMEIDA, J. M. et al. Avaliação da atividade antioxidante utilizando sistema $\beta$-caroteno/ácido linoléico e método de sequestro de radicais DPPH. Ciência e Tecnologia de Alimentos, v. 26, n. 2, p. 446-452, 2006.

ESPÍN, J. C. et al. Anthocyanin-based natural colorants: a new source of antiradical activity for foodstuff. Journal of Agricultural and Food Chemistry, v. 48, p. 1588-1592, 2000.

FRANCIS, F. J. Food colorants: anthocyanins. Critical Reviews in Food Science and Nutrition, v. 28, p. 273-314, 1989.

GUERRA, N. B.; MELO, E. A.; MANCINI FILHO, J. Antioxidant compounds from coriander (Coriandrum sativum L.) etheric extract. Journal of Food Composition and Analysis, v. 18, p. 193-199, 2004.

HAMMERSCHMIDT, P. A.; PRATT, D. E. Phenolic antioxidants of dried soybeans. Journal of Food Science, v. 43, p. 556-559, 1978.

HEINONEN, I. M.; LEHTONEN, P. J.; HOPIA, A. I. Antioxidant activity of berry and fruit wines and liquors. Journal of Agricultural and Food Chemistry, v. 46, p. 25-31, 1998.

JOHNSON, P. D. Acerola (Malpighia glabra L., M. punicifolia L., M. emarginata D.C.): agriculture, production and nutrition. World Review of Nutrition and Dietetics, v. 91, p. 67-75, 2003.

KÄHKÖNEN, M. P. et al. Berry anthocyanins: isolation, identification and antioxidant activities. Journal of the Science of Food and Agriculture, v. 83, p. 1403-1411, 2003.

KÄHKÖNEN, M. P.; HEINONEN, M. Antioxidant activity of anthocyanins and their aglycons. Journal of Agricultural and Food Chemistry, v. 51, p. 628-633, 2003.

LIMA, V. L. A. G. et al. Avaliação do teor de antocianinas em polpa de acerola congelada proveniente de frutos de 12 diferentes aceroleiras (Malpighia emarginata D.C.). Ciência e Tecnologia de Alimentos, v. 23, n. 1, p. 101-103, 2003.

LIMA, V. L. A. G. et al. Identificação de antocianidinas em acerolas do Banco Ativo de Germoplasma da Universidade Federal Rural de Pernambuco. Ciência e Tecnologia de Alimentos, v. 26, n. 4, p. 927-935, 2006.

LIMA, V. L. A. G. et al. Total phenolic and carotenoid contents in acerola genotypes harvested at three ripening stages. Food Chemistry, v. 90, n. 4, p. 565-568, 2005.

LIMA, V. L. A. G.; MELO, E. A.; GUERRA, N. B. Correlação entre o teor de antocianinas e caracterização cromática de polpas de diferentes genótipos de aceroleira. Brazilian Journal of Food Technology, v. 10, n. 1, p. 51-55, 2007.

MACHEIX, J.-J.; FLEURIT, A.; BILLOT, J. Fruit phenolics. Boca Raton: CRC, 1990.

MARCO, G. J. A rapid method for evaluation of antioxidants. Journal of the American Oil Chemist's Society, v. 45, p. 594-598, 1968.

MARKAKIS, P. Stability of anthocyanins in foods. In: Markakis, P. (Ed.). Anthocyanins as food colors. New York: Academic Press, 1982. p. 163-180. 
MELO, E. A. et al. Teor de fenólicos totais e capacidade antioxidante de polpas congeladas de frutas. Alimentos e Nutrição, v. 19, n. 1, p. 67-72, 2008.

MEZADRI, T. et al. Antioxidant compounds and antioxidant activity in acerola (Malpighia emarginata D.C.) fruits and derivatives. Journal of Food Composition and Analysis, v. 21, n. 4 , p. 282-290, 2008.

MILIAUSKAS, G.; VENSKUTONIS, P. R.; VAN BEEK, T. A. Screening of radical scavenging activity of some medicinal and aromatic plant extracts. Food Chemistry, v. 85, p. 231-237, 2004.

MUSSER, R. S. et al. Caracterização físico-química de acerolas do Banco Ativo de Germoplasma em Pernambuco. Ciência e Tecnologia de Alimentos, v. 24, n. 4, p. 556-561, 2004.

NAKAJIMA, J.-I. et al. LC/PDA/ESI-MS profiling and radical scavenging activity of anthocyanins in various berries. Journal of Biomedicine and Biotechnology, v. 5, p. 241-247, 2004.

OKI, T. et al. Involvement of anthocyanins and other phenolic compounds in radical-scavenging activity of purple-fleshed sweet potato cultivars. Journal of Food Science, v. 67, p. 1752-1756, 2002.

RIGHETTO, A. M.; NETTO, F. M.; CARRARO, F. Chemical composition and antioxidant activity of juices from mature and immature acerola (Malpighia emarginata D.C.). Food Science and Technology International, v. 11, n. 4, p. 315-321, 2005.

RODRIGUEZ-SAONA, L. E.; WROLSTAD, R. E. Extraction, isolation, and purification of anthocyanins. In: WROLSTAD, R. E. Current protocols in food analytical chemistry. New York: John Wiley \& Sons, 2001. p. 1.1-1.11.
RUFINO, M. S. M. et al. Free radical-scavenging behavior of some north-east Brazilian fruits in $\mathrm{DPPH}^{-}$system. Food Chemistry, v. 144, n. 2, p. 693-695, 2009.

SÁNCHEZ-MORENO, C. Review: methods used to evaluate the free radical scavenging activity in foods and biological systems. Food Science and Technology International, v. 8, p. 121-137, 2002.

SHARMA, O. P.; BHAT, T.K. DPPH antioxidant assay revisited. Food Chemistry, v. 113, n. 4, p. 1202-1205, 2009.

TABART, J. et al. Comparative antioxidant capacities of phenolic compounds measured by various tests. Food Chemistry, v. 113, n. 4, p. 1226-1233, 2009.

TEPE, B. et al. In vitro antioxidant activities of the methanol extracts of four Helichrysum species from Turkey. Food Chemistry, v. 90, p. 685-689, 2005.

VELIOGLU, Y. S. et al. Antioxidant activity and total phenolics in selected fruits, vegetables, and grain products. Journal of Agricultural and Food Chemistry, v. 46, p. 4113-4117, 1998.

VENDRAMINI, A. L.; TRUGO, L. C. Chemical composition of acerola fruit (Malpighia punicifolia L.) at three stages of maturity. Food Chemistry, v. 71, p. 195-198, 2000.

VINSON, J. A. et al. Phenol antioxidant quantity and quality in foods: vegetables. Journal of Agricultural and Food Chemistry, v. 46, p. 3630-3634, 1998.

WANG, H.; CAO, G.; PRIOR, R. L. Total antioxidant capacity of fruits. Journal of Agricultural and Food Chemistry, v. 44, p. 701-705, 1996. 